\title{
Penerapan Model Pembelajaran Kooperatif dengan Strategi Make A Match untuk Meningkatkan Kemampuan Komunikasi Matematika Siswa
}

\author{
Laeli Dwinurani Sujana $^{\text {,a) }}$, Juariah ${ }^{1}$, Karso ${ }^{1}$, dan Rahayu Kariadinata ${ }^{1}$ \\ ${ }^{1}$ Prodi Pendidikan Matematika, UIN Sunan Gunung Djati Bandung, \\ J1. A.H. Nasution No. 105, Cibiru , Bandung 40614, Indonesia \\ a)E-mail:pmtk@uinsgd.ac.id
}

\begin{abstract}
Abstrak .Komunikasi di dalam proses belajar sangat diperlukan karena komunikasi merupakan sesuatu yang utama dalam mengajar, menilai dalam pembelajaran matematika serta memudahkan dalam menyelesaikan permasalahan. komunikasi matematik mencakup beberapa hal yaitu kemampuan menulis, membaca, diskusi, evaluasi, dan berwacana. Disamping itu yang perlu diperhatikan adalah model pembelajaran yang diterapkan guna menghadapi era globalisasi. Untuk meningkatkan hasil belajar siswa salah satu model yang dapat digunakan dalam pembelajaran adalah Make a Match. Make a Match atau mencari pasangan merupakan salah satu alternatif yang dapat diterapkan kepada siswa
\end{abstract}

Kata Kunci: Make a match, komunikasi matematika

\section{Pendahuluan}

Salah satu tujuan pembelajaran matematika adalah untuk mengembangkan kemampuan mengkomunikasikan gagasan, antara lain melalui pembicaraan lisan, grafik, peta, diagram dalam menjelaskan gagasan.

Sehingga komunikasi di dalam proses belajar sangat diperlukan karena komunikasi merupakan sesuatu yang utama dalam mengajar, menilai dalam pembelajaran matematika dan komponen penting di dalam pemahaman konsep matematik siswa, sehingga tujuan pendidikan dapat tercapai sesuai dengan yang diharapkan.
Dengan kemampuan komunikasi matematik, siswa mungkin menggunakan bahasa verbal untuk mengkomunikasikan pikiran, memperluas proses berfikir dalam memahami konsep matematika. Kemampuan komnikasi matematik siswa tidak dapat terlepas dari indikator kemampuan komunikasi siswa menurut Ross (dalam Sofi, 2009: 11) yaitu: Menggambarkan situasi masalah dan menyatakan solusi masalah menggunakan gambar, bagan, tabel dan secara aljabar, menyatakan hasil dalam bentuk tertulis, menggunakan representasi menyeluruh untuk menyatakan konsep matematika dan solusinya membuat situasi matematika 
dengan menyediakan ide dan keterangan dalam bentuk tertulis, menggunakan bahasa matematika dan simbol secara tepat.

Karena itu kemampuan komunikasi matematik mencakup beberapa hal yaitu kemampuan menulis, membaca, diskusi, evaluasi, dan berwacana. Untuk melihat kemampuan komunikasi matematik siswa dalam pembelajaran dapat diperoleh dari karakteristik kemampuan komunikasi.

Selain komunikasi matematika, yang perlu diperhatikan model pembelajaran tidak kalah pentingnya diterapkan guna menghadapi era globalisasi adalah model pembelajaran kooperatif (cooperative learning). Menurut Lie (2008:18) "Pembelajaran Kooperatif bisa didefinisikan sebagai sistem kerja atau belajar kelompok yang terstruktur" .

Untuk meningkatkan hasil belajar siswa salah satu model yang dapat digunakan dalam pembelajaran adalah Make a Match. Menurut Tarmizi $\mathrm{R}$ model pembelajaran koopertif Make a Match atau mencari pasangan merupakan salah satu alternatif yang dapat diterapkan kepada siswa. Penerapan model ini dimulai dari teknik yaitu siswa disuruh mencari pasangan kartu yang merupakan jawaban/soal sebelum batas waktunya, siswa yang dapat mencocokkan kartunya diberi poin/reward.

Materi yang dipilih untuk melakukan penelitian ini adalah Diensi Tiga. Hal tersebut karena materi Dimensi Tiga sangat 20 berhubungan dengan simbol-simbol dan gambar-gambar sehingga komunikasi antara siswa ataupun dengan guru dapat terjalin dengan baik dan untuk memberikan kesempatan kepada siswa melakukan kerjasama dalam belajar dan berkompetisi.

Terdapat beberapa tujuan dilakukannya penelitian ini diantaranya untuk mengetahui proses pembelajaran, kemampuan komunikasi matematik siswa, perbedaan kemampuan komunikasi matematik siswa dan kemampuan guru dalam pengelolaan pembelajaran di kelas dengan menggunakan model pembelajaran kooperatif dengan strategi Make a Match pada pokok bahasan Dimensi Tiga serta mengetahui keterampilan kooperatif siswa selama bekerja dalam kelompok.

\section{Metodologi Penelitian}

Metode yang digunakan dalam penelitian ini adalah metode kuasi eksperimen, dimana peneliti ingin mengetahui hubungan sebab akibat setelah diberikan suatu perlakuan. Jenis penelitian adalah studi banding. Dengan metode ini peneliti akan membandingkan kemampuan komunikasi matematika siswa antara siswa di Madrasah Aliyah Negeri yang berperingkat tinggi, sedang, dan rendah dengan menggunakan model pembelajaran

Jurnal Analisa Vol 1 No.1 Juni 2013 :19-30 
Penerapan Model Pembelajaran

Kooperatif dengan Strategi Make A

Match untuk Meningkatkan Kemampuan

Komunikasi Matematika Siswa

kooperatif dengan strategi Make a Match pada pokok bahasan Dimensi Tiga.

Desain penelitian yang digunakan adalah desain kelas kelompok eksperimen. Ketiga kelompok (MAN) tersebut diberikan pendekatan pembelajaran yang sama yaitu kelompok eksperimen yang menggunakan model pembelajaran kooperatif dengan strategi Make a Match.

Dalam penelitian ini, peneliti akan mengadakan tes sebanyak dua kali yaitu tes awal (Pretest) dan tes akhir (Posttest). Tes awal dilaksanakan sebelum pembelajaran dilaksanakan dengan tujuan untuk mengetahui kemampuan komunikasi matematik siswa sebelum diberikan perlakuan. Adapun bentuk tes yang digunakan adalah uraian. Alasan peneliti memilih soal uraian ini yaitu agar proses berfikir, langkah-langkah pengerjaan, ketelitian serta kemampuan komunikasi matematik siswa dapat diketahui.

Lembar observasi adalah alat untuk mengukur tingkah laku individu (siswa/guru) ataupun proses terjadinya suatu kegiatan yang sedang diamati, baik dalam situasi yang sebenarnya ataupun dalam situasi buatan. Lembar observasi dapat mengukur atau menilai proses pembelajaran, misalnya tingkah laku siswa Jurnal Analisa Vol 1 No.1 Juni 2013 :19-30 pada saat belajar dan tingkah laku guru pada saat mengajar, kegiatan diskusi siswa, dan lain-lain.

Teknik pengumpulan data yang dilakukan dalam penelitian ini dilakukan dengan cara menentukan terlebih dahulu sumber data, jenis data, instrument yang digunakan, serta teknik pengumpulannya.

\section{Hasil dan Pembahasan}

Kemampuan Komunikasi Matematik Siswa Madrasah Aliyah Negeri

Untuk mengetahui kemampuan komunikasi matematik siswa di Madrasah Aliyah Negeri dengan menggunakan model pembelajaran kooperatif dengan strategi make a match pada pokok bahasan Dimensi Tiga terlebih dahulu ditentukan kualitas kemampuan komunikasi matematik siswa pada pretest dan posttest menggunakan pedoman klasifikasi kualitas kemampuan komunikasi matematik siswa. Setelah pretest dan posttest dikategorisasi berdasarkan aturan kategori (dalam Shinta, 2007: 24) maka diperoleh distribusi kategori untuk kemampuan komunikasi matematik siswa tiga kelas yang diterapkan dengan menggunakan model pembelajaran kooperatif dengan strategi make a match. 


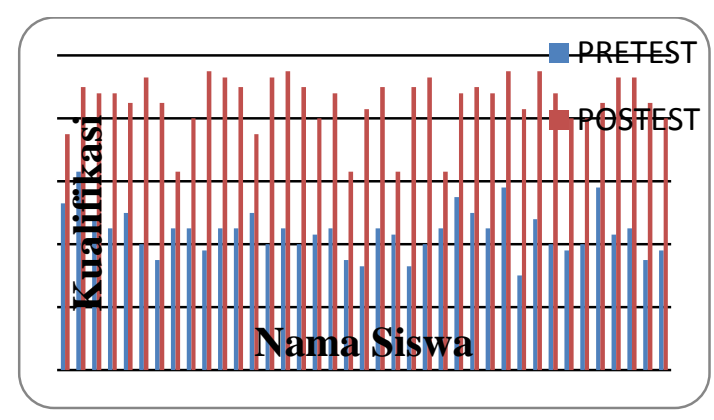

Gambar 3.9

Grafik Kemampuan Komunikasi Matematik Tiap Siswa di MAN 1

Tangerang

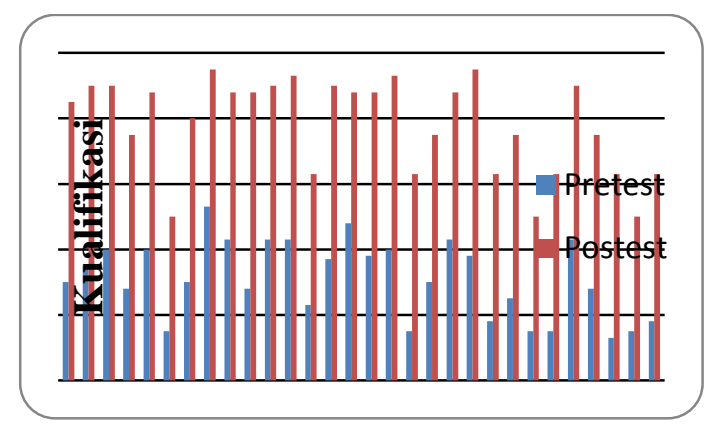

Gambar 3.11

Grafik Kemampuan Komunikasi Matematik Tiap Siswa di MAN 1 Cipondoh

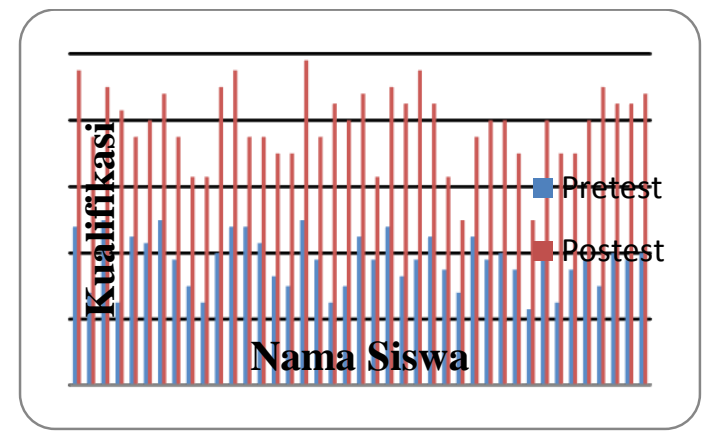

Gambar 3.13

Grafik Kemampuan Komunikasi Matematik Tiap Siswa di MAN Mauk
Berdasarkan kategorisasi data yang terlihat pada ketiga gambar diperoleh rata-rata kemampuan komunikasi matematik siswa pada saat pretest di MAN 1 Tangerang 17,49, MAN 1 Cipondoh 12,63 dan MAN Mauk 14,95 dengan nilai rata-rata terbesar pada pretest yaitu di MAN 1 Tangerang dengan nilai 17,49 . Nilai rata-rata kemampuan komunikasi matematika siswa pada saat posttest di MAN 1 Tangerang 33,71, MAN 1 Cipondoh 31,3 dan MAN Mauk 31,00 dengan nilai rata-rata terbesar posttest yaitu di MAN 1 Tangerang 33,71.

Dari hasil pretest dan posttest dari tiga sekolah ini peneliti membandingkan perkembangan siswa perindikator (dapat dilihat ditabel dan gambar perkembangan siswa perindikator) dari 5 indikator yang terdapat dalam indikator kemampuan komunikasi matematik siswa yaitu:

$\mathrm{K}_{1}=$ Menggambarkan situasi masalah dan menyatakan solusi masalah menggunakan gambar, bagan, tabel dan secara aljabar, $\mathrm{K}_{2}$ = Menyatakan hasil dalam bentuk tertulis, $\mathrm{K}_{3}=$ Menggunakan representasi menyeluruh untuk menyatakan konsep matematika dan solusinya, $\mathrm{K}_{4}=$ Membuat situasi matematika dengan menyediakan ide dan keterangan dalam bentuk tertulis $\mathrm{K}_{5}$ = Menggunakan bahasa matematika dan simbol secara tepat.

Tabel 3.6

Klasifikasi Hasil Tes Kelas X-1 MAN 1

Tangerang

\begin{tabular}{|l|l|}
\hline Indikator & Persentase (\%) \\
\hline
\end{tabular}

Jurnal Analisa Vol 1 No.1 Juni 2013 :19-30 
Penerapan Model Pembelajaran

Kooperatif dengan Strategi Make A

Match untuk Meningkatkan Kemampuan

Komunikasi Matematika Siswa

\begin{tabular}{|c|c|c|}
\hline \multirow{2}{*}{} & \multicolumn{2}{|c|}{$\begin{array}{c}\text { Kemampuan Komunikasi } \\
\text { Matematik Siswa }\end{array}$} \\
\cline { 2 - 3 } & Pretest & Postest \\
\hline$K_{1}$ & 64,1 & 100 \\
\hline$K_{2}$ & 53,85 & 89,74 \\
\hline$K_{3}$ & 51,28 & 89,74 \\
\hline$K_{4}$ & 58,97 & 100 \\
\hline$K_{5}$ & 61,54 & 94,87 \\
\hline
\end{tabular}

Tabel 3.7

Klasifikasi Hasil Tes Kelas X-1 MAN 1

Cipondoh

\begin{tabular}{|c|c|c|}
\hline \multirow{2}{*}{ Indikator } & \multicolumn{2}{|c|}{$\begin{array}{c}\text { Persentase (\%) } \\
\text { Kemampuan Komunikasi } \\
\text { Matematik Siswa }\end{array}$} \\
\cline { 2 - 3 } & Pretest & Postest \\
\hline$K_{1}$ & 60 & 93,33 \\
\hline$K_{2}$ & 43,33 & 83,33 \\
\hline$K_{3}$ & 46,67 & 83,33 \\
\hline$K_{4}$ & 50 & 100 \\
\hline$K_{5}$ & 56,67 & 83,33 \\
\hline
\end{tabular}

Tabel 3.8

Klasifikasi Hasil Tes Kelas X-1

MAN Mauk

\begin{tabular}{|c|c|c|}
\hline \multirow{2}{*}{ Indikator } & \multicolumn{2}{|c|}{$\begin{array}{c}\text { Persentase (\%) } \\
\text { Kemampuan Komunikasi } \\
\text { Matematik Siswa }\end{array}$} \\
\cline { 2 - 3 } & Pretest & Postest \\
\hline$K_{1}$ & 61,9 & 97,62 \\
\hline$K_{2}$ & 50 & 83,33 \\
\hline$K_{3}$ & 47,62 & 83,33 \\
\hline$K_{4}$ & 54,76 & 100 \\
\hline$K_{5}$ & 59,52 & 90,48 \\
\hline
\end{tabular}

Berdasarkan kategorisasi data yang terlihat pada ketiga gambar diperoleh kemampuan komunikasi matematik siswa perindikator (pada Lampiran C) saat pretest terletak antara $40 \%$ - 50\% dan setelah proses pembelajaran menggunakan model pembelajaran dengan strategi make a Jurnal Analisa Vol 1 No.1 Juni 2013 :19-30 match kemampuan komunikasi matematik isswa perindikator pada saat posttest naik dengan interval antara $80 \%-100 \%$.

Pengaruh pretest dan posttest terhadap ketiga sekolah tersebut dapat dihitung dengan Gain Ternormalisasi dengan perhitungan seperti pada (Lampiran C), dari data dapat diambil kesimpulan bahwa pengaruh pretest dan posttest terhadap tiga sekolah adalah sedang dengan rata-rata presentase pengaruhnya 54,61.

\section{Perbedaan Kemampuan Komunikasi Matematik Siswa MAN 1 Tangerang, MAN 1 Cipondoh, dan MAN Mauk}

Untuk mengetahui perbedaan kemampuan komunikasi matematik siswa antara siswa di Madrasah Aliyah Negeri dengan menggunakan model pembelajaran kooperatif dengan strategi make A match berdasarkan peringkat sekolah (tinggi, sedang, dan rendah), penulis menggunakan pengolahan data dengan ANOVA satu arah sehingga didapat hasil sebagai berikut.

Dari langkah-langkah ANOVA satu jalur pada $($ Lampiran $\mathrm{C})$ diperoleh nilai $\mathrm{F}_{\text {hitung }}=$ 108,01 dan $\mathrm{F}_{\text {tabel }}$ dengan $\mathrm{F}_{(0,05)(2 / 108)}=3,08$ dan $\mathrm{F}_{(0,01)(2 / 108)}=4,80$ maka diperoleh kesimpulan bahwa $F_{\text {hitung }}>F_{\text {tabel }}$ sehingga $\mathrm{H}_{\mathrm{o}}$ ditolak yaitu kemampuan komunikasi matematik siswa 3 sekolah tidak terdapat perbedaan satu sama lain dan $\mathrm{H}_{1}$ diterima 
yaitu kemampuan komunikasi matematik siswa 3 sekolah terdapat perbedaan satu sama lain.

Kesimpulan akhir dari analisis ANOVA satu arah 3 sekolah berdasarkan peringkat sekolah (tinggi, sedang, dan rendah) yaitu

Kemampuan Komunikasi Matematik Siswa Ketiga Sekolah Berbeda Secara Signifikan.

Dari data ANOVA satu jalur kita dapat mengetahui perlakuan mana dari ketiga sekolah yang paling efektif (baik) untuk menerapkan model pembelajaran kooperatif dengan strategi make a match dengan menghitung perbedaan rata-rata maksimum dari perhitungan pada (Lampiran C) dan diperoleh hasil PTS = 1,24 dan selisih rata-rata antara 3 sekolah.

Pada tabel perbedaan rata-rata diperoleh nilai rata-rata terbesar di MAN 1 Tangerang dan satu pasangan yaitu MAN 1 Cipondoh dengan MAN Mauk yang memiliki selisih nilai perbedaan rata-rata lebih kecil dari PTS yaitu 0,3 maka pengaruhnya penerapan model pembelajaran kooperatif dengan strategi make a match untuk meningkatkan kemampuan komunikasi matematik siswa di MAN 1 Cipondoh dan MAN Mauk adalah sama. Jika diurutkan peringkat berdasarkan pengaruhnya penerapan model pembelajaran kooperatif dengan strategi make a match untuk meningkatkan kemampuan komunikasi matematik siswa maka diperoleh urutan:
Pertama : MAN 1 Tangerang
Kedua : MAN 1 Cipondoh dan MAN Mauk

Penerapan model pembelajaran kooperatif dengan strategi make a match berdasarkan perhitungan ANAVA satu jalur pada (Lampiran C) lebih baik diterapkan di sekolah dengan peringkat sekolah tinggi pada penelitian ini diantara 3 sekolah yaitu MAN 1 Tangerang, MAN 1 Cipondoh dan MAN Mauk didapat Madrasah Aliyah Negeri 1 Tangerang yang lebih efektif diterapkan model pembelajaran kooperatif dengan strategi make a match untuk meningkatkan kemampuan komunikasi matematik siswa pada materi Dimensi Tiga kelas X.

Pembahasan Kemampuan Komunikasi
Matematika Siswa di MAN 1 Tangerang, MAN 1 Cipondoh dan MAN Mauk

Dari hasil penelitian tentang komunikasi matematika siswa di kelas X-1 MAN 1 Tangerang, MAN 1 Cipondoh dan MAN Mauk diperoleh kemampuan komunikasi matematika siswa terbesar pada saat pretest dan posttest di kelas X-1 MAN 1 Tangerang dan penerapan model Jurnal Analisa Vol 1 No.1 Juni 2013 :19-30 
Penerapan Model Pembelajaran

Kooperatif dengan Strategi Make A

Match untuk Meningkatkan Kemampuan

Komunikasi Matematika Siswa

pembelajaran kooperatif dengan strategi make a match lebih baik diterapkan di sekolah dengan tingkat sekolah tinggi pada penelitian ini di MAN 1 Tangerang. Banyak faktor-faktor yang mendukung mengapa MAN 1 Tangerang mempunyai kemampuan komunikasi matematika siswa tertinggi dan sekolah yang lebih baik diterapkannya model pembelajaran kooperatif dengan strategi make a match yaitu: Sekolah dengan rata-rata kelulusan tertinggi di Kota Tangerang setiap tahunnya dan menjadi salah satu madrasah aliyah unggulan di Kota Tangerang sehingga penerimaan siswa/i setiap tahunnya dengan seleksi yang sangat baik dilihat dari berbagai aspek kemampuan siswanya, para pengajar khususnya guru matematika yang memiliki kreativitas yang tinggi dalam proses belajar mengajar setiap harinya sehingga siswa/i mudah memahami materi yang sedang dibahas, kondisi sekolah yang nyaman jauh dari keramaian kendaraan sehingga proses belajar mengajar lebih kondusif, siswa/i yang sangat kreatif dalam proses pembelajaran yaitu mendengarkan penjelasan guru, pelaksanaan tugas, tanyajawab, diskusi, dan berkelompok.

MAN 1 Cipondoh dan MAN Mauk memiliki kemampuan komunikasi Jurnal Analisa Vol 1 No.1 Juni 2013 :19-30 matematika yang sama dan bisa juga diterapkan model pembelajaran kooperatif dengan strategi make a match karena setelah dilakukan penelitian diperoleh peningkatan hasil tes siswa/i sebelum dan sesudah diterapkannya model pembelajaran kooperatif dengan strategi make a match.

\section{Gambaran Proses Pembelajaran Dengan Menggunakan Model Pembelajaran Kooperatif Dengan Strategi Make A Match}

Untuk mengetahui bagaimana gambaran proses pembelajaran dengan menggunakan model pembelajaran kooperatif dengan strategi make a match penulis menggunakan lembar observasi. Pengamatan dilakukan oleh satu orang observer di tiga sekolah yang memahami model pembelajaran yang digunakan terhadap guru yang memberikan pembelajaran yaitu peneliti sendiri.

Kepada pengamat diminta memberikan penilaian untuk proses pembelajaran kooperatif dengan strategi make a match. Adapun kategori penilaiannya adalah: baik (skor 4), cukup baik (skor 3), kurang baik (skor 2) dan tidak baik (skor 1). Sedangkan aspek pengolahan yang diamati adalah: Ketersiapan kartu-kartu pertanyaan, 
jawaban \& lembar pertanyaan \& jawaban, Pelaksanaan pembagian kelompok pemegang kartu pertanyaan, jawaban \& penilai, Pengaturan tempat pelaksanaan pembelajaran berbentuk U, Pembagian kartu-kartu pertanyaan, jawaban \& lembar pertanyaan \& jawaban, Menginformasikan proses pembelajaran dengan Make a Match, Keterlaksaan proses pembelajaran dengan informasi, Mengevaluasi Permasalahan yang ada dan Penilian kemudian pembagian reward bagi siswa dengan nilai tertinggi.

Untuk lebih jelasnya mengenai penilaian gambaran proses pembelajaran dengan menggunakan model pembelajaran kooperatif dengan strategi make a match dapat dilihat dalam (Lampiran D) diperoleh rata-rata penilaian 3,2 dengan kriteria cukup baik dalam proses pembelajaran dengan menggunakan model pembelajaran kooperatif dengan strategi make a match.

\section{Kemampuan Guru dalam Pembelajaran Koperatif Make A Match}

Untuk mengetahui bagaimana kemampuan guru dalam pengelolaan pembelajaran di kelas dengan menggunakan model pembelajaran kooperatif dengan strategi make a match penulis menggunakan lembar observasi. Pengamatan dilakukan oleh satu orang observer di tiga sekolah yang memahami model pembelajaran yang digunakan terhadap guru yang memberikan pembelajaran yaitu peneliti sendiri.

Kepada pengamat diminta memberikan penilaian untuk proses pembelajaran kooperatif dengan strategi make a match. Adapun kategori penilaiannya sama dengan gambaran proses pembelajaran. Sedangkan aspek pengolahan yang diamati adalah: Pendahuluan meliputi apersepsi serta motivasi terhadap siswa, kegiatan inti meliputi presentasi kelas, pembentukan kelompok, pembagian kartu, pencarian pasangan kartu, diskusi kelompok, penjelasan hasil diskusi, pemberian skor dan reward, kemudian penutup meliputi kesimpulan dan pemberian tugas.

Untuk lebih jelasnya mengenai kemampuan guru dalam menggunakan model pembelajaran kooperatif dengan strategi make a match dapat dilihat dalam (Lampiran D) diperoleh rata-rata penilaian 3,4 dengan kriteria cukup baik kemampuan guru dalam menggunakan model pembelajaran kooperatif dengan strategi make a match.

\section{Kemampuan Keterampilan Kooperatif} Siswa

Untuk mengetahui bagaimana keterampilan kooperatif siswa selama bekerja dalam kelompok, penulis Jurnal Analisa Vol 1 No.1 Juni 2013 :19-30 
Penerapan Model Pembelajaran

Kooperatif dengan Strategi Make A

Match untuk Meningkatkan Kemampuan

Komunikasi Matematika Siswa

menggunakan lembar observasi. Pengamatan dilakukan oleh peneliti sendiri selama kegiatan pembelajaran kooperatif dengan strategi make a match berlangsung, peneliti melihat hasil perolehan poin siswa setiap pertemuan menggunakan model pembelajaran make a match. Adapun proses kegiatan pembagian kartu-kartu akan peneliti uraikan:

Kegiatan pembelajaran dengan menggunakan model pembelajaran make a match dilakukan setiap selesai pembahasan sedikit materi dari guru atau peneliti. Peneliti menyiapkan kartu-kartu pertanyaan dan jawaban soal yang jumlah kartu pertanyaan sama dengan jumlah kartu jawaban.

Setelah kartu-kartu selsesai dibereskan dan siap dibagikan, guru terlebih dahulu membagi siswa dalam 3 kelompok yang heterogen, jumlah siswa kelompok pertanyaan harus sama dengan jumlah siswa kelompok jawaban dimana kemampuan tiap siswa dalam tiap kelompok berbeda.

Setelah posisi kelompok sudah rapih dan siap maka guru membagikan kartu-kartu pertanyaan dan jawaban. Setelah setiap siswa dikelompok pertanyaan dan jawaban Jurnal Analisa Vol 1 No.1 Juni 2013 :19-30 memperoleh satu kartu maka setiap kelompok bersiap-siap mencari pasangannya dan membentuk kelompok kecil yang terdiri dari 3 orang (1 kelompok pertanyaan, 1 kelompok jawaban, dan 1 kelompok juri) maka kelompok kecil itu berdiskusi tentang kartu jawaban dan kartu pertanyaan yang mereka peroleh, jika hasil jawaban diskusi berbeda dengan kartu jawaban yang ada maka juri harus mencari kartu jawaban yang sesuai dengan jawaban hasil diskusi kemudian menyalin dalam sehelai kertas untuk diberikan kepada guru.

Setelah habis waktu berdiskusi dan terkumpul semua hasil diskusi dari kelompok kecil maka guru memilih secara acak hasil diskusi dan mengambil beberapa kertas hasil diskusi dan kelompok kecil yang terambil kertasnya hasil diskusi wajib mempresentasikannya di depan kelas.

Diberikan kesempatan kepada siswa yang memberikan masukan, tanggapa, atau sanggahan dari presentasi teman di depan.

Setelah semua presentasi selesai maka guru beserta murid bersama-sama menyimpulkan hasil pembelajaran yang sedikit penjelasan jika ada permasalahan yang belum selesai dalam diskusi. Nilai sudah dilaksanakan dan guru memberi 
terbesar dari salah satu siswa mendapatkan reward. Setelah hasil penelitian diperoleh hasil rata-rata adalah 3 dari 3 kelompok yaitu (pertanyaan, jawaban dan juri) dengan kriteria cukup baik dalam pelaksanaan pembelajaran.

\section{Simpulan dan Saran}

Berdasarkan hasil penelitian tentang pengaruh model pembelajaran kooperatif dengan strategi make a match untuk meningkatkan kemampuan komunikasi matematik siswa yang dilaksanakan di MAN 1 Tangerang, MAN 1 Cipondoh, dan MAN Mauk secara garis besar dapat disimpulkan kemampuan komunikasi matematik siswa di Madrasah Aliyah Negeri berdasarkan peringkat sekolah (tinggi, sedang, dan rendah) yaitu saat pretest sebelum diterapkan model pembelajaran kooperatif dengan strategi make a match diperoleh ratarata kemampuan komunikasi matematik siswa tertinggi pada saat pretest di MAN 1 Tangerang, dan pada saat posttest sesudah diterapkannya model pembelajaran kooperatif dengan strategi make a match diperoleh ratarata kemampuan komunikasi matematika siswa tertinggi pada saat posttest di MAN 1 Tangerang. Perbedaan kemampuan komunikasi matematik siswa antara siswa di Madrasah Aliyah Negeri dengan menggunakan model pembelajaran kooperatif dengan strategi Make A Match pada pokok bahasan Dimensi Tiga berdasarkan peringkat sekolah (tinggi, sedang, dan rendah) dengan menggunakan pengolahan data ANOVA satu arah sehingga didapat hasil bahwa kemampuan komunikasi matematik 28 tertinggi terdapat di MAN 1 Tangerang dengan peringkat sekolah tinggi dan kemampuan komunikasi matematik kedua terdapat di MAN 1 Cipondoh dan MAN Mauk dengan peringkat sekolah sedang dan rendah. Gambaran proses pembelajaran dengan menggunakan model pembelajaran kooperatif dengan strategi Make A Match pada pokok bahasan Dimensi Tiga dengan menggunakan lembar observasi diperoleh kriteria cukup baik dalam proses pembelajaran dengan menggunakan model pembelajaran kooperatif dengan strategi make a match, kemampuan guru dalam pengelolaan pembelajaran di kelas dengan menggunakan model pembelajaran kooperatif dengan strategi Make A Match dengan menggunakan lembar observasi diperoleh kriteria cukup baik kemampuan guru dalam menggunakan model pembelajaran kooperatif dengan strategi make a match, keterampilan kooperatif siswa selama bekerja dalam kelompok dengan menggunakan lembar observasi dari 3 kelompok yaitu (pertanyaan, jawaban dan juri) dengan kriteria cukup baik dalam pelaksanaan pembelajaran .

Dengan melihat hasil yang didapat, ada beberapa hal yang ingin penulis sampaikan, diantaranya perlu kiranya model pembelajaran kooperatif dengan strategi make a match ini digunakan oleh guru kelas $\mathrm{X}$ pada materi pokok Dimensi Tiga dan pada materi pokok lainnya, karena pada materi pokok Dimensi Tiga menunjukkan hasil yang efektif dan baik untuk lebih meningkatkan kemampuan komunikasi matematik siswa dan diharapkan pada materi pokok yang lainnya, kemampuan Jurnal Analisa Vol 1 No.1 Juni $2013: 19-30$ 
Penerapan Model Pembelajaran

Kooperatif dengan Strategi Make A

Match untuk Meningkatkan Kemampuan

Komunikasi Matematika Siswa

komunikasi matematik siswa perlu ditingkatkan lagi dibeberapa sekolah yang kemampuan komunikasi matematika siswanya kurang karena komunikasi matematik merupakan salah satu keterampilan proses matematika, dalam pelaksaan pembelajaran perlu adanya kreatifitas dari guru dan siswa dalam penggunaan alat-alat peraga yang menunjang proses pembelajaran sehingga mudah dipahami.

\section{Daftar Pustaka}

Addin Grahaddin Affandi. 2007. Matematika X Membangun Cara Berpikir Ilmiah. SMA Al-Mas'soem: Bandung.

Agus Suprijono. 2009. Cooperatif Learning. Pustaka Pelajar: Yogyakarta.

Anas Sudijono. 1996. Pengantar Evaluasi Pendidikan. Jakarta: Rajawali Press.

Anita Lie. 2008. Cooperative Learning. Jakarta: Grasindo.

Asep Jihad. 2008. Pengembangan Kurikulum Matematika. Yogyakarta: Imperia Press.

B. K. Noormandiri dan Endar Sucipto. 2004. Matematika SMA untuk Kelas $X$. Erlangga: Jakarta.

Dede Sulaeman. 2005. Teknik Probing dalam Upaya Meningkatkan Kemampuan Komunikasi Matematik Jurnal Analisa Vol 1 No.1 Juni 2013 :19-30
Siswa MTs Al-Jawami. (Penelitian Tindakan Kelas Terhadap Siswa Kelas VII B MTs Al-Jawami Bandung). (Skripsi) UIN Sunan Gunung Djati Bandung: Tidak dipublikasikan.

E. Yulia Rachmawati. 2007. Kemampuan Komunikasi Matematik Siswa SMPN I Sukarame Melalui pendekatan Problem Based-Learning. (Penelitian Eksperimen di Kelas VII SMPN I Sukarame-Tasikmalaya). (Skripsi) Tidak dipublikasikan.

Himpunan Peraturan Undang-Undang. 2009. Undang-Undang Guru dan Dosen. Bandung: Fokusmedia.

Portia C Elliot and Margaret J Kenny. 1996. Communication In Mathematics. Virginia: The National Council Of Teachers Of Mathematics.

Rahayu Kariadinata. 2006. Aplikasi Multimedia Interaktif dalam Upaya Mengembangkan Kemampuan Berpikir Matematik Tingkat Tinggi Siswa SMA. (Studi Eksperimen pada Siswa SMA Negeri di Kota Bandung). (Disertasi) UPI Bandung: Tidak Dipublikasikan.

Richard $\mathrm{R}$ Hake. 1998. InteractiveEngagement VS Traditional Methods: A Six Thousand Student UIN Sunan Gunung Djati Bandung: Pembelajaran Matematika Sevagai 
Laeli Dwinurani Sujana, Juariah, Karso, dan Rahayu Kariadinata

Survey of Mechanics Test Duta For Introductory

Course.

http://www.eric.edu.gov/ericdocs/d ata/ericdocs 2 sql/content storage 0 $1 / 0000196 / 80 / 16 / 30 / 10$ pdf

Diakses pada tanggal 5 Februari 2010.

Robert E. Slavin. 2009. Cooperative Learning Teori, Rise dan Praktik. Nusa Media: Bandung.

Sartono Wirodikromo. 2006. Matematika untuk SMA Kelas X. Erlangga: Jakarta.

Shinta Indriawati Hilman. 2007. Penerapan Model Pembelajaran Kooperatif Tipe TGT (Times Gimes Tournament) Untuk Meningkatkan Kemampuan Komunikasi Matematik Siswa. (Penelitian Eksperimen di Kelas VIII SMP Negeri 6 Garut). (Skripsi) UIN Sunan Gunung Djati Bandung: Tidak dipublikasikan.

Sofi Safitri. 2009. Penerapan Peta Konsep dalam Upaya Meningkatkan Kemampuan Komunikasi Matematik Siswa. (Penelitian Tindakan Kelas terhadap Siswa Kelas VIII A SMP Ganesa Plus Cimanggung Bandung). (Skripsi) UIN Sunan Gunung Dajti Bandung: Tidak dipublikasikan.

Suharsimi Arikunto. 2000. Manajemen Penelitian. Jakarta: Rineka Cipta.

Suharsimi Arikunto. 2007. Dasar-Dasar Evaluasi Pendidikan. Jakarta: Bumi Aksara.

Suherman dan Sukjaya. 1990. Petunjuk Praktis untuk Melaksanakan Evaluasi Pendidikan Matematka. Bandung: Wijaya Kusuma.
Sudjana. 2007. Metode Statistika. Bandung: Tarsito.

Sumarna Surapratama. 2005. Analisis, Validitas, Reliabilitas dan Interpretasi Hasil Tes Implementasi Kurikulum 2004. Bandung: PT. Remaja Rosdakarya Offset.

Tarmizi Ramadhan. 2008. Pembelajaran Kooperatif "Make A Match". http//tarmizi.wordpress.cow/2008/12/0 3/pembelajaran-kooperatif-make-amatch/ Diakses pada tanggal 2 Oktober 2009.

Wilson Simangunsong. 2005. PKS Matematika Kelas X Sekolah Menengah Atas dan Madrasah Aliyah. Gematama: Jakarta.

Wina Sanjaya. 2008. Strategi Pembelajaran. Jakarta: Kencana Prenada Media Group. 